ACTA SCIENTIFIC DENTAL SCIENCES (ISSN: 2581-4893)

Volume 4 Issue 7 July 2020

\title{
Non-Surgical Management of Unusually Large Chronic Recurrent Periapical Abscess and an Insight on Periapical Radiolucencies
}

\author{
Swati Gupta ${ }^{1}$, Ramakant Gupta ${ }^{2 *}$ and Manju Gupta ${ }^{3}$ \\ ${ }^{1}$ Senior Consultant, Oral and Maxillofacial Pathology, Dr. Jatinder Gupta's Gupta Clinic \\ and Opticals, Haryana, India \\ ${ }^{2}$ Head and Consultant, Department of Dental Services, Dr. Jatinder Gupta's Gupta \\ Clinic and Opticals, Haryana, India \\ ${ }^{3}$ Director and Clinic coordinator, Dr. Jatinder Gupta's Gupta Clinic and Opticals, \\ Haryana, India
}

*Corresponding Author: Ramakant Gupta, Head and Consultant, Department of Dental Services, Dr. Jatinder Gupta's Gupta Clinic and Opticals, Haryana, India.

Received: April 02, 2020

Published: June 22, 2020

(C) All rights are reserved by Ramakant

Gupta., et al.

\begin{abstract}
Recurrent inflammatory periapical lesions are commonly encountered oral pathologies. The usual cause of these periapical lesions is endodontic in nature and can be easily treated by endodontic treatment. They exhibit wide biologic behaviors and their presentation as recurrent pus discharging ulcers can lead to patient's apprehension and even be cause for clinician's anxiety. This is because many non-endodontic causes may also lead to periapical lesions. A thorough knowledge about them therefore, is crucial for clinicians not only to properly diagnose and manage such cases, but is also important to safeguard themselves from patient's evil intentions of making easy money by claiming refund. The present case is one such example where unusually large chronic recurrent periapical abscess was managed with non- surgical endodontic treatment. With this case report, authors intend to discuss the different periapical radiolucencies and explain scientific guidelines for their adequate diagnosis and management.
\end{abstract}

Keywords: Endodontic; Non-endodontic; Periapical; Recurrent; Radiolucency

\section{Introduction}

Recurrent inflammatory periapical lesions are common afflictions presenting in dental clinics. They are easily diagnosed by presence of periapical radiolucency in radiograph and usually have an endodontic cause. Sometimes, their chronic presence as recurrent pus discharging ulcers can lead to patient's apprehension. A highly apprehensive patient with unresolved dilemmas can become a cause of anxiety even for the clinician. This is because periapical radiolucencies may have non-endodontic causes as well [1]. To manage such cases adequately, clinicians must have thorough knowledge of different periapical radiolucencies which remains enigmatic for most. Clinician's awareness about the contest is also crucial to safeguard themselves from patient's evil intentions of making easy money by claiming refund. The present case is one such example where unusually large chronic recurrent periapical abscess was managed with non- surgical endodontic treatment. With this case report, authors intend to discuss the different periapical radiolucencies, and explain scientific guidelines for their adequate diagnosis and management.

\section{Case Report}

Forty one (41) years old female patient reported to department of dental services in Asian Institute of Medical Sciences with the chief complain of reoccurring ulcers with pus discharge in lower front gums since 3 - 4 years. Patient was quiet apprehensive about the same. On eliciting history of presenting illness, patient revealed that the ulcers developed spontaneously at intervals of approximately 15 days to one month. The ulcers gradually increased in size and then resolved by themselves within a week after pus discharge. There were no other associated symptoms. Patient consulted private practitioner in her vicinity approximately one year back for the same and undergone a root canal treatment in 32. However, similar ulcers and pus discharge after approximately 2 months of completion of treatment lead to the patient's apprehension. Further, the patient's fear against cancer added onto the same. Patient was scared that she might be suffering from a major illness which remains undiagnosed since long. 
On intraoral examination, oval erythematous area, approximately $2-3 \mathrm{~mm}$ in diameter was seen immediately adjacent to frenum on right side (Figure 1). It was non- tender and no blood/ pus discharge was seen. Generalized calculus deposition on teeth was seen. Temporary restoration was present in 32. A provisional diagnosis of recurrent periapical abscess in 32 was made and an RVG was done.

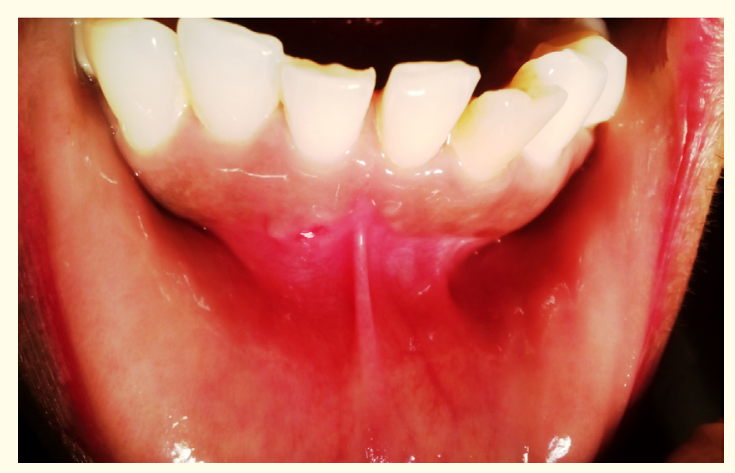

Figure 1: Pretreatment photograph showing erythematous area adjacent to frenum on right side.

RVG (Figure 2) revealed a large periapical radiolucency of approximately $8.0 \times 10.0 \mathrm{~mm}$ involving 41,31 , and 32 . Widening of periodontal ligament space in coronal and middle third and loss of lamina dura at apex of 41,31 and 32 was seen. The Gutta Percha in 32 was approximately $2.5-3 \mathrm{~mm}$ short of apex. Vitality test was performed and 41 and 31 were found to be non-vital. A final diagnosis of chronic recurrent periapical abscess was made.

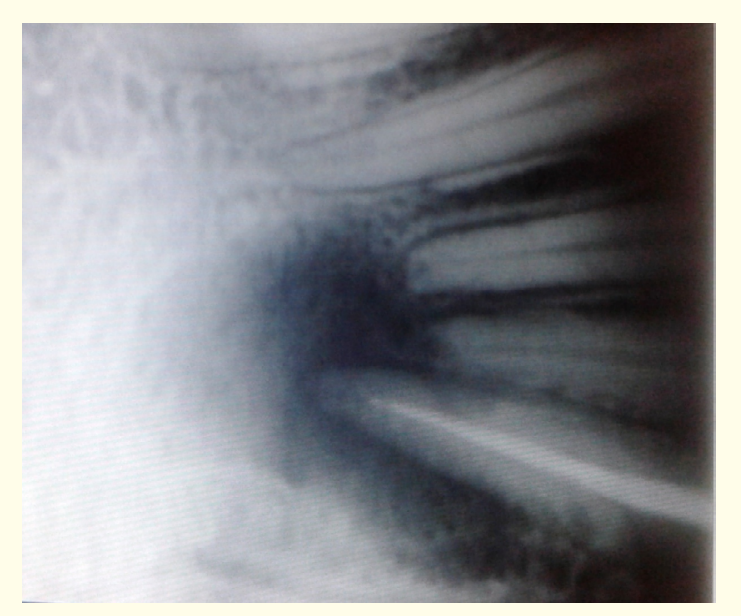

Figure 2: Pretreatment diagnostic radiograph.
Patient's apprehension was the major impediment in the treatment. She was explained about the other causes of periapical radiolucencies along with hers. All the options to treat the present case i.e. nonsurgical endodontic management, apicoectomy and extraction along with their pros and cons were also explained. Patient opted for non- surgical management and after taking informed consent from the patient, treatment was started.

Oral prophylaxis was performed, access opening in 41, 31 and 32 was made and Gutta Percha from 32 was removed. A strong odour discharge from canals was present. Canals were debrided using normal saline, sodium hypochlorite, 17\% EDTA, dentchlor, shaped using mechanical instrumentation and intracanal calcium hydroxide and iodoform (calplus) dressing was placed. Dressings were changed six times at a week's interval over a period of one and a half month.

During the treatment no ulcerations/symptoms were seen. When the canals were free of any discharge, they were dried and sealed using gutta percha and AHplus (Figure 3). Post obturation restoration was done after one week. Oral hygiene instructions were given and patient was kept warm saline rinses and gum paint and recalled for follow-up every 15 days. Patient is asymptomatic since 3 months and clinical examination revealed intact mucosa (Figure 4) and radiographic healing of lesion (Figure 5).

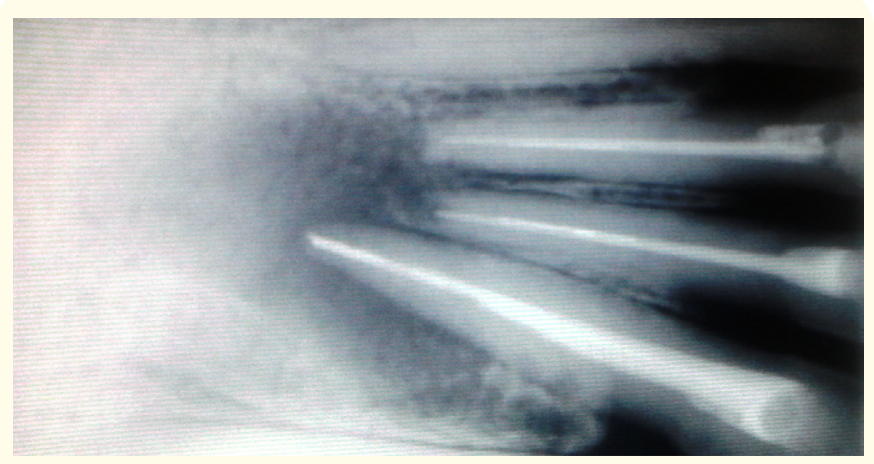

Figure 3: Post obturation radiograph.

\section{Discussion}

The highlight of the present case is the patient's apprehension regarding her chronic illness which also acted as a major obstacle at a point during the treatment and was dealt with. Whenever an $\mathrm{x}$-ray with periapical radiolucency presents to a clinician, first and foremost an endodontic cause is thought off and an endodontic 


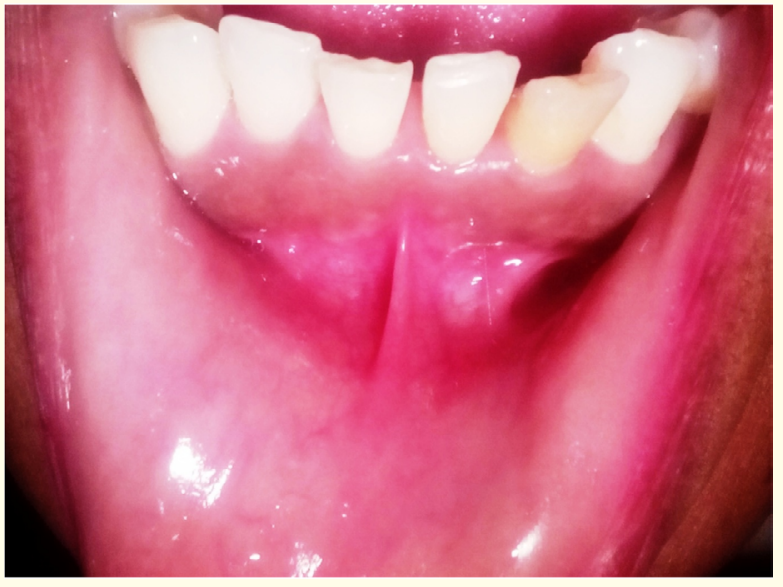

Figure 4: Photograph showing intact mucosa.

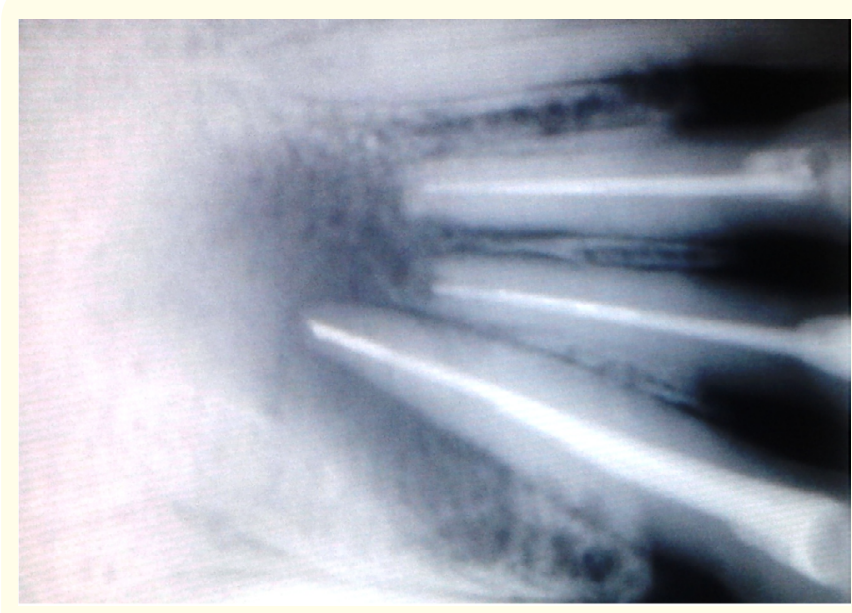

Figure 5: Radiograph showing signs of healing.

treatment is rendered. However, there may be other non-endodontic causes as well. In presence of these non-endodontic causes, the periapical lesions remain unhealed by endodontic treatment and cause patient dissatisfaction [1]. To diagnose, counsel and manage such cases adequately, it is imperative for clinicians to be aware of non-endodontic causes also.

The endodontic causes of periapical radiolucencies include [1] periapical granuloma/cyst/abscess [2,3], Condensing Osteitis or Focal Chronic Sclerosing Osteomyelitis [2,3], and periapical scar [2-4]. Non-endodontic periapical radiolucencies are caused by odontogenic and nonodontogenic cysts [1], benign and malignant jaw tumors [5] and infectious diseases [1,6,7]. Their clinical, radiographic, histopathological features and management has been tabulated in table 1.
To differentiate endodontic and non-endodontic causes of periapical lesions it is important to adequately record medical, dental history, intraoral examination including dental hard and soft tissues as well as radiological findings [1]. Endodontic periapical lesions do not separate from root apex by changing radiographic angles [8]. Pulp vitality tests can serve as a diagnostic measure and help in differentiation of endodontic cause. They help to distinguish vital tooth from nonvital but cannot differentiate between different pathologies. If the involved tooth is found to be vital then, the nonendodontic cause is confirmed and biopsy is required to diagnose [9]. However, endodontic cause cannot be ascertained by negative vitality test [10]. If endodontic cause is confirmed and patient has pain during the instrumentation without local anaesthesia, the diagnosis should be suspected and further evaluation might be required [1]. If the lesion shows growth in size or remains unchanged after a year of adequate endodontic treatment, then, other causes must be suspected [11]. Histopathologic evaluation of periapical lesions is crucial were endodontic treatment has been failed [12]. American Association of Endodontics has put forward the guidelines suggested by Gallego Romero., et al. for treatment of periapical lesions are tabulated in table 2 [9]. About $12 \%$ of all periapical lesions have non-endodontic causes [13]. Biopsy and histopathologic evaluation of such lesions can help in reaching adequate diagnosis, thereby proper treatment planning [13]. The indications of biopsy as recommended by Razavi SM, Kiani S., et al. are summarized in table 3 [1].

In the present case, involved teeth were intact, with a substantial calculus deposition. Thus, it might be possible that the abscess progressed to the periapical area through periodontium and lead to non- vital teeth. Absence of oral prophylaxis and previous inadequate endodontic treatment lead to the reoccurrence of lesion. Patient however, tried to threaten the treating clinician for refund of whole treatment cost during follow-up, but was counselled and managed adequately.

There are numerous case reports in English literature on nonsurgical management of periapical lesions; but to the author's best knowledge, none has reported non- surgical management of a periapical lesion of such a large extent. The present case is first one to do so and is thought to be rare.

\section{Conclusion}

Periapical lesions are commonly encountered and can exhibit wide biologic behaviours. Onus lies on clinicians to adequately diagnose them and avoid endodontic mistreatment. Therefore, they 


\begin{tabular}{|c|c|c|c|c|}
\hline Periapical lesion & Clinical features & Radiographic features & Histopathological features & Management \\
\hline \multicolumn{5}{|c|}{ Periapical lesions due to endodontic causes } \\
\hline $\begin{array}{l}\text { Periapical Granu- } \\
\text { loma }\end{array}$ & $\begin{array}{l}\text { Asymptotic unless acute } \\
\text { inflammatory reactions } \\
\text { cause initiating symptoms } \\
\text { like pain, swelling, fever, } \\
\text { and lymphadenopathy }\end{array}$ & $\begin{array}{l}\text { Well-defined or ill- } \\
\text { defined radiolucency, } \\
\text { at root apex, Widening } \\
\text { of periodontal ligament } \\
\text { space in apical part of } \\
\text { the root/lamina dura } \\
\text { and root resorption }\end{array}$ & $\begin{array}{l}\text { Periapical granuloma } \\
\text { contains infiltration of } \\
\text { inflammatory cells such as } \\
\text { polymorphonuclear leuko- } \\
\text { cytes (PMN), lymphocytes, } \\
\text { macrophages and plasma } \\
\text { cells, which are supported by } \\
\text { granulation tissue }\end{array}$ & $\begin{array}{c}\text { Extraction, root canal } \\
\text { therapy, apical surgery, or } \\
\text { in some cases, the combi- } \\
\text { nation of these }\end{array}$ \\
\hline Radicular Cyst & $\begin{array}{l}\text { Asymptotic unless acute } \\
\text { inflammatory reactions } \\
\text { cause initiating symptoms } \\
\text { like pain, swelling }\end{array}$ & $\begin{array}{l}\text { Exhibits thin radi- } \\
\text { opaque line around } \\
\text { periphery of radiolucent } \\
\text { area indicating reac- } \\
\text { tion of bone to slowly } \\
\text { expanding mass }\end{array}$ & $\begin{array}{l}\text { Cystic Cavity lined by nonke- } \\
\text { ratinized stratified squamous } \\
\text { epithelium, fibrous con- } \\
\text { nective tissue wall shows } \\
\text { infiltration of inflammatory } \\
\text { cells and small blood vessels, } \\
\text { cholesterol clefts, macro- } \\
\text { phages and multinucleated } \\
\text { giant cells are also seen }\end{array}$ & $\begin{array}{c}\text { Extraction, root canal } \\
\text { therapy, apical surgery, or } \\
\text { in some cases, the combi- } \\
\text { nation of these }\end{array}$ \\
\hline $\begin{array}{l}\text { Condensing } \\
\text { Osteitis or Focal } \\
\text { Chronic Scleros- } \\
\text { ing Osteomyelitis }\end{array}$ & $\begin{array}{l}\text { Mandible > maxilla, } \\
\text { prevalent in molars, focal } \\
\text { lesion in periapical area of } \\
\text { the teeth with necrotic or } \\
\text { inflamed pulps, extended } \\
\text { caries, and restorations, } \\
\text { may be seen in the teeth } \\
\text { with inappropriate root } \\
\text { canal therapy and the teeth } \\
\text { under occlusal trauma }\end{array}$ & $\begin{array}{l}\text { Local homogeneous ra- } \\
\text { diodensity in root apex } \\
\text { area of the teeth with } \\
\text { PDL widening, does not } \\
\text { have radiolucent margin }\end{array}$ & $\begin{array}{l}\text { Sclerosis and remodeling of } \\
\text { bone, If the adjacent inflam- } \\
\text { matory cells infiltrated into } \\
\text { the sclerotic bone, necrosis } \\
\text { often occurs }\end{array}$ & $\begin{array}{l}\text { Similar to other inflam- } \\
\text { matory endodontic } \\
\text { lesions; in some cases, } \\
\text { however, radiopacity } \\
\text { without symptoms is } \\
\text { observed after conven- } \\
\text { tional treatment. In these } \\
\text { cases, retreatment is not } \\
\text { required }\end{array}$ \\
\hline Periapical Scar & $\begin{array}{l}\text { Reparative response, which } \\
\text { is characterized by the } \\
\text { formation of dense collagen } \\
\text { fibers instead of the mature } \\
\text { bone, } \\
\text { Asymptomatic }\end{array}$ & $\begin{array}{l}\text { Nonhealing radiolucen- } \\
\text { cies in periapical areas } \\
\text { of the teeth with favor- } \\
\text { able root canal therapy }\end{array}$ & Fibrous tissue & $\begin{array}{l}\text { Retreatment is not re- } \\
\text { quired }\end{array}$ \\
\hline \multicolumn{5}{|c|}{ Periapical lesions due to nonendodontic causes } \\
\hline $\begin{array}{l}\text { Nasopalatine Duct } \\
\text { Cyst }\end{array}$ & $\begin{array}{l}1.3 \% \text { to } 4.2 \% \text { of nonodon- } \\
\text { togenic cyst, asymptomatic, } \\
\text { but sometimes show pain, } \\
\text { swelling of the anterior } \\
\text { palate, response to palpa- } \\
\text { tion of buccal and palatal } \\
\text { structures, and pus drain- } \\
\text { age. Teeth adjacent to these } \\
\text { lesions are vital }\end{array}$ & $\begin{array}{l}\text { Well-defined radiolu- } \\
\text { cency in the maxillary } \\
\text { midline or between } \\
\text { the apexes of central } \\
\text { incisors roots. root } \\
\text { resorption. This cyst can } \\
\text { be misdiagnose as an } \\
\text { inflammatory periapical } \\
\text { lesion when radio- } \\
\text { graphs show a superim- } \\
\text { position of the incisor } \\
\text { canal or foramen over } \\
\text { the apex of maxillary } \\
\text { central incisors }\end{array}$ & $\begin{array}{l}\text { Cystic lesion lined by ciliated } \\
\text { stratified squamous epithe- } \\
\text { lium with fibrous connec- } \\
\text { tive tissue wall, and various } \\
\text { degrees of inflammatory cells }\end{array}$ & Surgical enucleation \\
\hline $\begin{array}{l}\text { Simple Bone } \\
\text { Cyst/ traumatic } \\
\text { bone cyst }\end{array}$ & $\begin{array}{l}\text { Fluid contained benign cav- } \\
\text { ity in the jaw bone, which } \\
\text { lacks epithelial cover }\end{array}$ & $\begin{array}{l}\text { Rarely seen as a well or } \\
\text { ill-defined radiolucency } \\
\text { in periapical area. If } \\
\text { this lesion has involved } \\
\text { several teeth, scalloped } \\
\text { prominence among the } \\
\text { dental roots is seen }\end{array}$ & $\begin{array}{l}\text { Walls of the defect is lined } \\
\text { by a thin band of fibrous } \\
\text { connective tissue or thicken } \\
\text { myxofibromatous prolif- } \\
\text { eration, which often has } \\
\text { trabeculae of reactive bone }\end{array}$ & $\begin{array}{c}\text { Exploratory surgery is } \\
\text { necessary for diagnosis } \\
\text { and is usually sufficient } \\
\text { therapy }\end{array}$ \\
\hline
\end{tabular}




\begin{tabular}{|c|c|c|c|c|}
\hline $\begin{array}{l}\text { Odontogenic } \\
\text { Keratocyst }\end{array}$ & $\begin{array}{c}\text { Comprises about } 0.7 \% \\
\text { of all periapical cysts, Af- } \\
\text { fects posterior area of the } \\
\text { mandible, usually asymp- } \\
\text { tomatic, but some present } \\
\text { with pain, swelling, and pus } \\
\text { drainage, has an aggressive } \\
\text { behavior and high rates of } \\
\text { recurrence }\end{array}$ & $\begin{array}{l}\text { Unilocular or multilocu- } \\
\text { lar well-defined radio- } \\
\text { lucency with or without } \\
\text { root resorption }\end{array}$ & $\begin{array}{l}\text { Cystic lining consists of a } \\
\text { relatively uniform layer of } \\
\text { parakeratinized stratified } \\
\text { squamous epithelium with } \\
\text { six-cell to ten-cell thickness } \\
\text { without rete ridge formation } \\
\text { and with corrugated surface. } \\
\text { The basal layer of cuboidal to } \\
\text { columnar cells with hyper- } \\
\text { chromatic and palisaded } \\
\text { nuclei is observed. The con- } \\
\text { nective tissue wall may show } \\
\text { epithelial islands or daughter } \\
\text { cyst, and some cases may } \\
\text { have acute or chronic inflam- } \\
\text { mation }\end{array}$ & $\begin{array}{l}\text { Enucleation and curet- } \\
\text { tage, Due to high rates of } \\
\text { recurrence, the patient } \\
\text { with this lesion should } \\
\text { be followed up after five } \\
\text { years of treatment }\end{array}$ \\
\hline $\begin{array}{l}\text { Lateral Periodon- } \\
\text { tal Cyst }\end{array}$ & Asymptomatic, & $\begin{array}{l}\text { Misdiagnosed as a } \\
\text { lateral radicular cyst, } \\
\text { because of the similar } \\
\text { radiographic features } \\
\text { including radiolucency } \\
\text { along lateral root sur- } \\
\text { face }\end{array}$ & $\begin{array}{c}\text { Cystic cavity lined by thin } \\
\text { stratified squamous epitheli- } \\
\text { um and in some area, by focal } \\
\text { nodular thickening }\end{array}$ & $\begin{array}{l}\text { Conservative enucle- } \\
\text { ation without root canal } \\
\text { therapy }\end{array}$ \\
\hline $\begin{array}{l}\text { Calcifying odonto- } \\
\text { genic cyst (COC) } \\
\text { or Gorlin's cyst }\end{array}$ & $\begin{array}{c}\text { Asymptomatic, mandible } \\
=\text { maxilla, } 65 \% \text { of these } \\
\text { lesions are in the anterior } \\
\text { jaw }\end{array}$ & $\begin{array}{c}\text { Unilocular or multilocu- } \\
\text { lar well-defined radiolu- } \\
\text { cency and occasionally } \\
\text { with diffuse radiopaque } \\
\text { areas }\end{array}$ & $\begin{array}{l}\text { Cystic cavity with a fibrous } \\
\text { capsule and an odontogenic } \\
\text { epithelium lining, with epi- } \\
\text { thelium basal cells similar } \\
\text { to ameloblasts, presence } \\
\text { of ghost cells within the } \\
\text { epithelium. Calcification area } \\
\text { are seen }\end{array}$ & Enucleation of the lesion \\
\hline $\begin{array}{c}\text { Central Giant Cell } \\
\text { Granuloma }\end{array}$ & $\begin{array}{l}\text { Common in anterior seg- } \\
\text { ments of the jaws and } \\
\text { usually crosses through } \\
\text { the midline, Nonaggres- } \\
\text { sive type has slow growth } \\
\text { and low recurrence rate, In } \\
\text { aggressive type, the rapid } \\
\text { growth, high rate of recur- } \\
\text { rence }\end{array}$ & $\begin{array}{l}\text { Well-defined unilocular } \\
\text { or multilocular radiolu- } \\
\text { cency, Root resorption } \\
\text { and cortical perforation } \\
\text { is uncommon in Nonag- } \\
\text { gressive type, cortical } \\
\text { bone perforation, root } \\
\text { resorption, and tooth } \\
\text { displacement in aggres- } \\
\text { sive type }\end{array}$ & $\begin{array}{l}\text { Proliferating endothe- } \\
\text { lial cells, fibroblasts and } \\
\text { myofibroblasts, small blood } \\
\text { vessels, and multinucleated } \\
\text { giant cells in a connective } \\
\text { tissue }\end{array}$ & $\begin{array}{l}\text { Involved teeth of this le- } \\
\text { sion are vital. Treatment } \\
\text { is curettage, but radical } \\
\text { surgery may be needed } \\
\text { for aggressive type }\end{array}$ \\
\hline Ameloblastoma & $\begin{array}{c}\text { Second most common } \\
\text { odontogenic tumor after } \\
\text { odontomas, mandible is the } \\
\text { common site }\end{array}$ & $\begin{array}{l}\text { Three different types } \\
\text { of clinicoradiologic fea- } \\
\text { tures including conven- } \\
\text { tional solid, unicystic } \\
\text { and peripheral. }\end{array}$ & $\begin{array}{l}\text { Several histopathologic } \\
\text { subtypes are recognized. The } \\
\text { most common histopatho- } \\
\text { logic pattern is follicular that } \\
\text { is comprised of the islands of } \\
\text { loosely arranged cells resem- } \\
\text { bling the stellate reticulum } \\
\text { of enamel organ which } \\
\text { surrounding by columnar } \\
\text { ameloblastic-like cells with } \\
\text { reversed polarity. }\end{array}$ & $\begin{array}{l}\text { Marginal resection of at } \\
\text { least } 1.0 \text { to } 1.5 \mathrm{~cm} \text { beyond } \\
\text { the radiologic limits of } \\
\text { the tumor }\end{array}$ \\
\hline Ossifynig Fibroma & $\begin{array}{l}\text { Posterior region of the } \\
\text { mandible is the most com- } \\
\text { mon site, rare benign jaw } \\
\text { neoplasm, often asymptom- } \\
\text { atic, and in some cases lead } \\
\text { to swelling of the cortical } \\
\text { plate of the jaw }\end{array}$ & $\begin{array}{l}\text { Based on the amount } \\
\text { of calcified material, } \\
\text { radiographic view could } \\
\text { be mixed radiolucent } \\
\text { and radiopaque }\end{array}$ & $\begin{array}{l}\text { Shows connective tissue } \\
\text { of variable cellularity with } \\
\text { mineral component in the } \\
\text { form of trabecular or woven } \\
\text { bones. }\end{array}$ & $\begin{array}{l}\text { Complete excision of the } \\
\text { tumor }\end{array}$ \\
\hline
\end{tabular}




\begin{tabular}{|c|c|c|c|c|}
\hline $\begin{array}{l}\text { Periapical Ce- } \\
\text { mental Dysplasia } \\
\text { (Cementoma) }\end{array}$ & $\begin{array}{l}\text { Jaw fibrosseous lesions that } \\
\text { often involves the periapi- } \\
\text { cal region of the anterior } \\
\text { mandible, usually asymp- } \\
\text { tomatic }\end{array}$ & $\begin{array}{l}\text { In early stage, well- } \\
\text { defined unilocular } \\
\text { radiolucency involv- } \\
\text { ing root apex, loss of } \\
\text { lamina dura. In second } \\
\text { stage of maturation/ } \\
\text { mixed stage, radiopaque } \\
\text { components within the } \\
\text { radiolucent area. In final } \\
\text { stage, the lesion may be } \\
\text { totally radiopaque with } \\
\text { radiolucent border }\end{array}$ & $\begin{array}{l}\text { Show the cellular mesenchy- } \\
\text { mal tissue and collagen fibers } \\
\text { with small blood vessels, a } \\
\text { mixture of woven or lamellar } \\
\text { bones, and cementum-like } \\
\text { particles }\end{array}$ & $\begin{array}{l}\text { Because of tendency for } \\
\text { expansion of jaw, extrac- } \\
\text { tion of tooth is done }\end{array}$ \\
\hline Cementoblastoma & $\begin{array}{l}\text { Comprises }<1 \% \text { of odonto- } \\
\text { genic tumors, true neo- } \\
\text { plasm of cemental origin, } \\
\text { Mandible }>\text { maxilla, grow } \\
\text { slowly, usually asymptom- } \\
\text { atic, occasionally have mild } \\
\text { pain. localized expansion of } \\
\text { cortical plates of bone }\end{array}$ & $\begin{array}{l}\text { Well-defined radiopaci- } \\
\text { ty with a cortical border, } \\
\text { which is confined by a } \\
\text { radiolucent margin, }\end{array}$ & $\begin{array}{l}\text { Cementum like tissue de- } \\
\text { posited in globular pattern, } \\
\text { reversal lines scattered } \\
\text { throughout, variable soft tis- } \\
\text { sue component consisting of } \\
\text { fibrillar, vascular and cellular } \\
\text { channels }\end{array}$ & $\begin{array}{l}\text { Because of tendency for } \\
\text { expansion of jaw, extrac- } \\
\text { tion of tooth is done }\end{array}$ \\
\hline $\begin{array}{l}\text { Malignant Jaw } \\
\text { Lesions Lym- } \\
\text { phoma, leukemia, } \\
\text { multiple my- } \\
\text { eloma, squamous } \\
\text { cell carcinoma, } \\
\text { adenocarcinoma, } \\
\text { chondrosarcoma, } \\
\text { osteosarcoma, } \\
\text { and metastatic } \\
\text { lesions }\end{array}$ & $\begin{array}{l}\text { Existence of dental caries, } \\
\text { root resorption, irregular } \\
\text { radiolucency, and localized } \\
\text { tooth mobility without } \\
\text { periodontal disease indi- } \\
\text { cates the need for further } \\
\text { investigation. Moreover, } \\
\text { observation of sensation } \\
\text { disorder, previous end- } \\
\text { odontic treatment failure, } \\
\text { unusual pain, and swelling } \\
\text { emphasize on the necessity } \\
\text { of more radiographic and } \\
\text { clinical or histopathologic } \\
\text { evaluations }\end{array}$ & $\begin{array}{l}\text { Ill-defined radiolucency } \\
\text { without cortical border, } \\
\text { bony islands in the } \\
\text { radiolucent area can } \\
\text { create a patchy appear- } \\
\text { ance, unusual symptoms } \\
\text { including bone destruc- } \\
\text { tion with rapid or slow } \\
\text { growth adjacent to the } \\
\text { vital teeth }\end{array}$ & $\begin{array}{c}\text { Varied histologic features, } \\
\text { show tumor cells, dedifferen- } \\
\text { tiation/ anaplasia, invasion } \\
\text { in vital structures }\end{array}$ & $\begin{array}{l}\text { Biopsy and complete } \\
\text { resection of tumor and } \\
\text { radiotherapy. }\end{array}$ \\
\hline Infection Disease & $\begin{array}{l}\text { Actinomycosis, histoplas- } \\
\text { mosis, and aspergillosis }\end{array}$ & Varied features & $\begin{array}{l}\text { Band of fibrous connective } \\
\text { tissue with chronic inflam- } \\
\text { matory cells infiltration and } \\
\text { colonies of organisms }\end{array}$ & $\begin{array}{l}\text { In addition to endodon- } \\
\text { tic treatment, antibiotic } \\
\text { therapy, and occasionally, } \\
\text { apical surgery is required }\end{array}$ \\
\hline $\begin{array}{l}\text { Granulomatous } \\
\text { Inflammation }\end{array}$ & $\begin{array}{l}\text { Foreign body reaction, } \\
\text { fungal and mycobacterial } \\
\text { infections, and choles- } \\
\text { terol derivatives from cell } \\
\text { necrosis }\end{array}$ & Variable & $\begin{array}{l}\text { Shows diffuse infiltrate of } \\
\text { macrophages and multinu- } \\
\text { cleated giant cells, formation } \\
\text { of typical granulomas }\end{array}$ & $\begin{array}{l}\text { Biopsy and complete } \\
\text { removal of the lesion is } \\
\text { necessary }\end{array}$ \\
\hline
\end{tabular}

Table 1: Salient features of clinical, radiographic, histopathological features and management of periapical lesions.

\begin{tabular}{|c|c|c|}
\hline S. No. & Periapical Lesion & Therapeutic Approach \\
\hline 1. & Diameter $<5 \mathrm{~mm}$ & Conservative approach, short-term follow-up \\
\hline 2. & $\begin{array}{c}\text { Diameter of } 5 \text { - } 10 \mathrm{~mm} \text { with endodontic } \\
\text { diagnosis }\end{array}$ & Conventional root canal therapy, 3 months follow-up \\
\hline 3. & No healing in 3 months after treatment & Consultation with oral and maxillofacial surgeon before retreatment \\
\hline 4. & Diameter $>10 \mathrm{~mm}$ & $\begin{array}{l}\text { Consultation with oral and maxillofacial surgeon for apicoectomy and conven- } \\
\text { tional root canal therapy }\end{array}$ \\
\hline
\end{tabular}

Table 2: Guidelines of the American association of endodontics for periapical lesions [9]. 


\begin{tabular}{|c|c|}
\hline S. No. & Indications \\
\hline & Lesions involving periapical area of vital tooth \\
\hline & Persistent or continuously growing periapical lesion even after adequate endodontic treatment \\
\hline & $\begin{array}{c}\text { Persistent periapical lesion even after adequate endodontic re- treatment } \\
\text { Periapical lesions showing advancing mobility of involved or adjacent teeth in absence of periodontal disease and irregular }\end{array}$ \\
\hline & Periapical lesions which shows any change and separate from root apex with changing radiographic angulations \\
\hline & Periapical lesion with unusual radiographic features involving tooth without caries or with low caries \\
\hline & Persistent Periapical lesion with unusual symptoms such as sensation disorders \\
\hline
\end{tabular}

Table 3: Indications of biopsy as recommended by Razavi SM., et al [1].

should be aware of the indications of biopsy and other paraclinical tests and refer the patient to Oral and Maxillofacial pathologist/ Surgeon wherever required.

\section{Acknowledgements}

Authors declare that they did not receive any sponsorship and financial support for the paper. Authors acknowledge the divine presence and blessings of Late. Dr. Jatinder Kumar Gupta and dedicate whole work to him. Further, authors acknowledge the writing support provided by Angel Medical Solutions and express an enormous gratitude towards Dr. Nitin Goel for all his support and encouragement all the time during the work. Also, authors sincerely acknowledge and extend warm gratitude towards Dr. Geetika Virdi Sharma and Dr. Sunil Valecha for all their efforts in counselling the patient. Authors shall also like to thank Mr. Anil Kumar for his assistance and Mr. Mahesh, Mr. Mukesh, Mr. Layakram and whole team for their support.

\section{Conflict of Interest}

Authors declare that there are no financial interests or any conflict of interest.

\section{Bibliography}

1. Razavi SM., et al. "Periapical Lesions: a Review of Clinical, Radiographic, and Histopathologic Features". Avicenna Journal of Dental Research 7.1 (2015): e19435.

2. Chapman MN., et al. "Periapical lucency around the tooth: radiologic evaluation and differential diagnosis". Radiographics 33.1 (2013): e15-e32.

3. Nair PN. "On the causes of persistent apical periodontitis: a review”. International Endodontic Journal 39.4 (2006): 249-281.
4. Gupta R., et al. "Non-Surgical Management of Mandibular Molar with Multiple Intra-oral Sinus Tracts: A Case Report". Journal of Clinical and Diagnostic Research 7.10 (2013): 23922393.

5. Hutchison IL., et al. "Neoplasia masquerading as periapical infection". British Dental Journal 168.7 (1990): 288-294.

6. Al-Hezaimi K. "Apical actinomycosis: case report". Journal of the Canadian Dental Association 76(2010): a113.

7. Nair PN., et al. "Therapy-resistant foreign body giant cell granuloma at the periapex of a root-filled human tooth". Journal of Endodontics 16.12 (1990): 589-595.

8. Neville BW., et al. "Oral and Maxillofacial Pathology". $3^{\text {rd }}$ edition Missouri: Saunders/Elsevier (2009).

9. Gallego Romero D., et al. "Differential diagnosis and therapeutic approach to periapical cysts in daily dental practice". Medicina Oral Patologia Oral y Cirugia Bucal 7.1 (2002): 54-58.

10. Ortega A., et al. "Nonendodontic periapical lesions: a retrospective study in Chile". International Endodontic Journal 40.5 (2007): 386-390.

11. Torabinejad M., et al. "Endodontics: Principles and Practice". St Louis: Saunders Elsevier (2009).

12. Liapatas S, et al. "Inflammatory infiltrate of chronic periradicular lesions: an immunohistochemical study". International Endodontic Journal 36.7 (2003): 464-471. 
13. Omoregie OF., et al. "A clinicopathologic correlation in the diagnosis of periradicular lesions of extracted teeth". Journal of Oral and Maxillofacial Surgery 67.7 (2009): 1387-1391.

\section{Assets from publication with us}

- Prompt Acknowledgement after receiving the article

- Thorough Double blinded peer review

- Rapid Publication

- Issue of Publication Certificate

- High visibility of your Published work

Website: www.actascientific.com/

Submit Article: www.actascientific.com/submission.php

Email us: editor@actascientific.com

Contact us: +919182824667

Citation: Ramakant Gupta., et al. "Non-Surgical Management of Unusually Large Chronic Recurrent Periapical Abscess and an Insight on Periapical Radiolucencies". Acta Scientific Dental Sciences 4.7 (2020): 64-71. 